\title{
INFLUENCE OF CABLE LENGTH ON THE VIBRATING WIRE SENSORS DYNAMIC MEASUREMENTS
}

\author{
G.CIEPLOK ${ }^{1}$, W. KARWOWSKI ${ }^{2}$, L. BEDNARSKI $^{3}$
}

\begin{abstract}
The hereby paper discusses the influence of cable length on the SHM systems with the use of vibrating wire dynamic measurements. Vibrating wire sensors are mainly used for measuring stable or slowly changing strains, e.g. system installed on Rędziński Bridge in Wroclaw. From some time applications of these sensors for measuring dynamic deformations are becoming popular. Such tests were conducted on STS Fryderyk Chopin. New solutions generate new problems. In this case: the operational stability of systems exciting wire vibrations. The structure of such sensors and the electric cables length has an essential influence on their operations, what is undertaken in the paper. The subject of investigations constitutes the measuring system based on self-exciting impulse exciter, for which impedance parameters of electric cables and of the vibrating wire sensor were the most essential. The mathematical model of the system, experimental verification of the model as well as the results of theoretical analyses at the application of electric cables of various lengths are presented in the paper.
\end{abstract}

Keywords: vibrating wire sensors, structural health monitoring, tall ship mast, bridge, transient states, cable connections, self-oscillation

\section{INTRODUCTION}

The hereby paper discusses the influence of cable length on the Structural Health Monitoring systems with the use of vibrating wire dynamic measurements. Vibrating wire sensors found applications in

\footnotetext{
${ }^{1}$ DSc., PhD., Eng., AGH University of Science and Technology, ul. Mickiewicza 30, 30-059 Krakow, Poland, e-mail: cieplok@agh.edu.pl

${ }^{2}$ PhD., Eng., Warsaw University of Technology, Faculty of Civil Engineering, Al. Armii Ludowej 16, 00-637 Warsaw, Poland, e-mail: w.karwowski@il.pw.edu.pl

3 PhD., Eng., AGH University of Science and Technology, ul. Mickiewicza 30, 30-059 Krakow, Poland, e-mail: bednarski@agh.edu.pl
} 
measuring and monitoring of engineering structures like: bridges [15][16], dams, tunnels [10], stadiums [10] etc. The vibrating wire measurement technology became an important branch of the metrology applied in measurements of elements displacements versus each other, strains, changes of crack width, changes in pressure angles of building objects, foundation settlements, ground pressure on structure elements, etc.

They owe their popularity to simple construction, full resistance to environmental conditions and very long time stability, according to research of the Norwegian Geotechnical Institute, over 30 years [2]. The principle of operation of this system is presented in Fig.1.

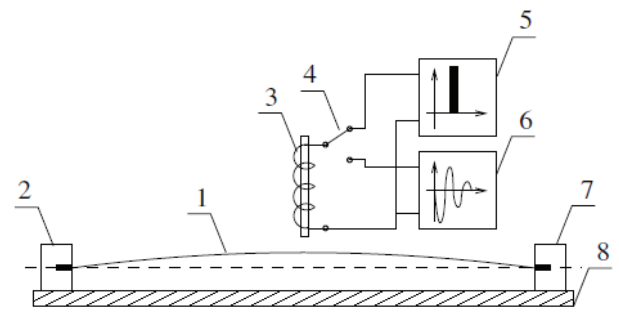

Fig. 1. Principle of operation of the strain transducer: 1 - wire, 2,7 - catches, 3 - electromagnet, 4 - switch, 5 - pulser, 6 - analyser, 8 - base.

The basic element of the sensor is the wire excited for vibrations by means of a coil. A change in the measured value, e.g. strain, displacement or water pressure, causes a change in the wire tension, which changes its natural frequencies. The vibrating wire induces in the coil a variable voltage at a frequency equal to the natural frequency of the string, which is recorded by the measuring electronics. Because the information about the measured value is transmitted by voltage changes (frequency), wire sensors can work with cables with lengths up to $12 \mathrm{~km} \mathrm{[2],} \mathrm{which} \mathrm{allows} \mathrm{sensors} \mathrm{to} \mathrm{be} \mathrm{placed} \mathrm{anywhere} \mathrm{in} \mathrm{the}$ structure, often in a hardly accessible areas and to be connected to electronic devices placed in an easily accessible service areas.

The standard time of single measurement with a vibrating wire sensors is approx. 1 second. Such a long measurement time is not a limitation in the measuring systems dedicated to longterm structural health monitoring. An example of such a system is the system installed on the Rędziński Bridge across the Odra River in Wrocław [1] [3], the sketch plan of which is shown in Figure 2. There are 96 vibrating wire sensors for displacements, strains and angular deflections measurements.

Rędziński Bridge is $122 \mathrm{~m}$ high (pylon) and $612 \mathrm{~m}$ long bridge object - it is the bigest concrete (prestressed concrete) bridge in Poland. The possiblity of using sensors with any lenght cables allowed to decoupled sensors location and data aquisition equipement location. Sensors could be installed in 
any place on the bridge (top of the pylon, pylon foundation, both ends of the bridge deck etc.) and data aquisition computers could be installed in locations, whiach are easy avialble for service. All vibrating wire sensors work as longterm monitoring sensors with measuremetn period of 15 minutes.

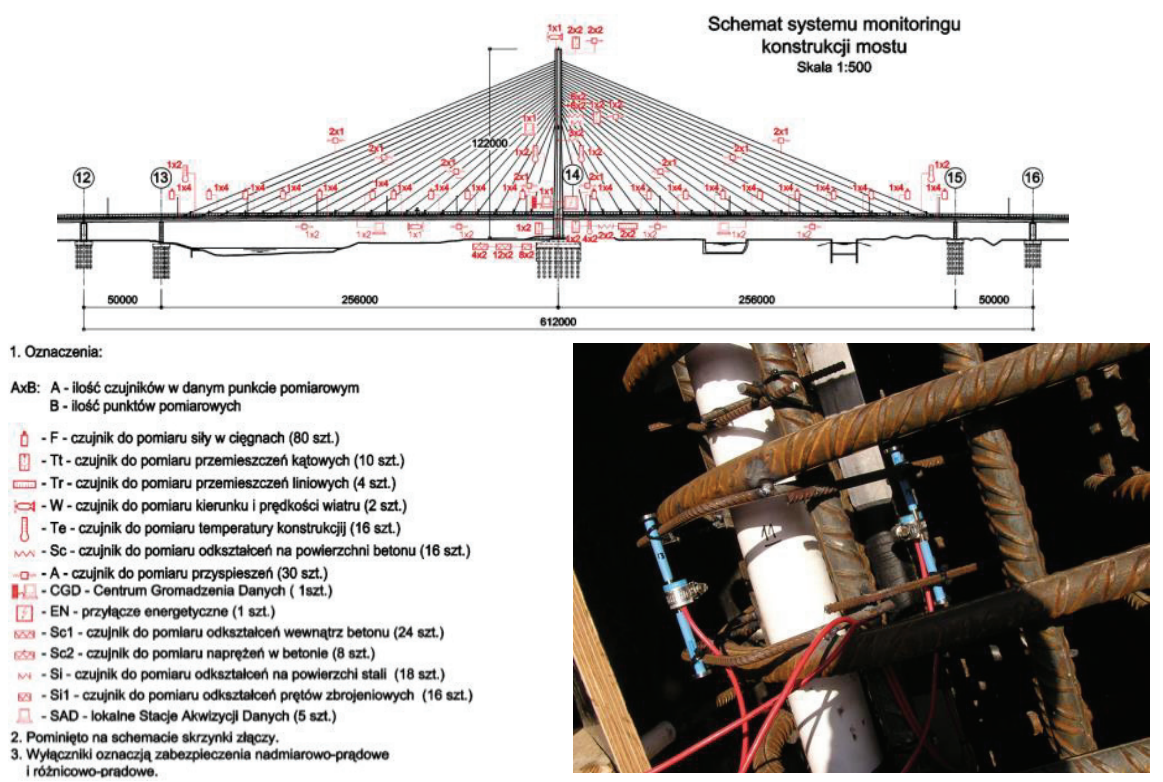

Fig. 2. Sketch plan of the Structural Health Monitoring system on Rędziński Bridge and example of vibrating wire strain gauges in pylon foundation [1] [3]

The needs of designers, contractors and object operators show that low frequency measurements (static ones) are not enough. When loads are dynamic (vehicles, wind), it becomes necessary to conduct measurements, where sensors allow to obtain a response with variability of the measured values at least 100 times per second.

The development of measuring technologies allows for using of vibrating wire sensors for such fastchanging measurements [8][9]. The change concerns the data acquisition and measurements enforcing devices, not the sensors themselves. This means that already installed systems can be easily supplemented with a completely new character of data recording. The measured strains (stresses) histogram made on the basis of high frequency measurements data is the basis for fatigue analysis. Such analysis is necessary to assess the durability of heavily used structures exposed to dynamic loads, eg bridges [11] [14] [16]. 
An interesting example of the application of vibrating wire sensors for dynamic measurements is the structural monitoring of the steel mast of the sailing tall ship Fryderyk Chopin during the selected sea maneuvers. As part of this research, two series of dynamic measurement tests were carried out with Geokon Model 4000 vibrating wire sensors, a CDM-VW305 Campbell Scientific device supported by DVWTool v. 1.2 software. The foremast was chosen for tests. Foremast was treated as a multispan beam with stays on several levels and fixed bottom end, whisch is loaded with unknown horizontal concentrated forces applied at the yard heigth. During the first series of measurements [13] sensors were located - mainly due to easy access - just above the ship deck. At the second series [12] the location of the sensors was above the first and second mast platform. The meserment frequency was $20 \mathrm{~Hz}$.
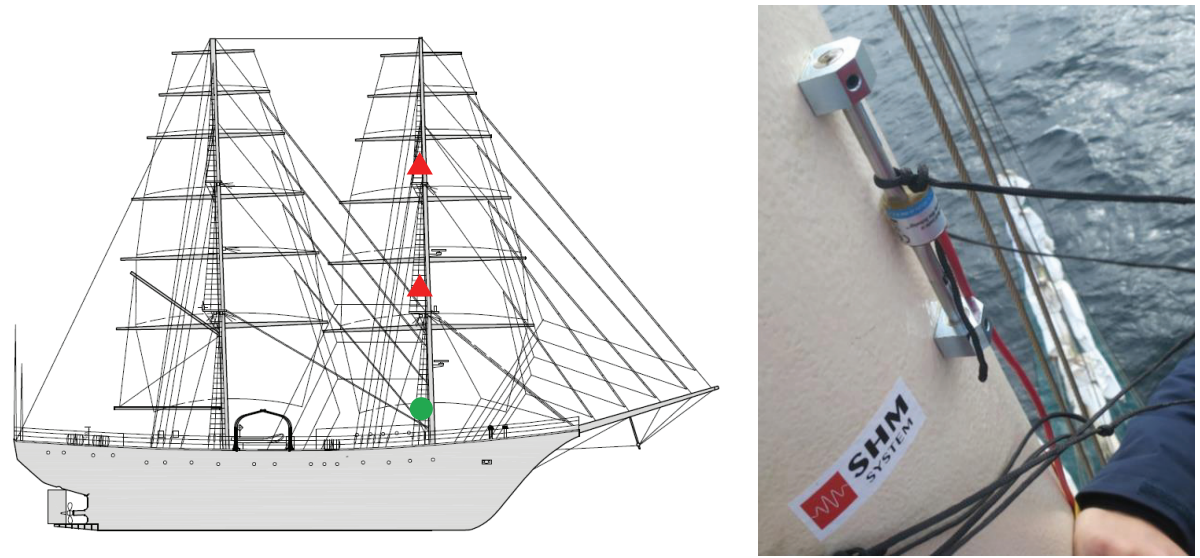

Fig. 3. STS Fryderyk Chopin side view with location of sensors in the first (circle) and the second (triangles) measurements series. Installation of vibrating wire strain gauges [12] [13].

Because of the temporary nature of the installation and its pilot nature, at the ship owner's request, the sensors were mounted only with epoxy glue. In the first case directly on the preppared steel surface of the mast. In the second case on the existing protective coating of the structure. In the first case sensors were installed just above the deck level and were exposed to very difficult environmental conditions (high salinity, high humidity or work in direct contact with water - sea waves crashing on the deck). Vibrating wire sensors fulfilled their function - because of their sealed casing they did not require additional protection. 
The sensors were mounted in each of the cross-sections at four points $(3+1$ for controll) symmetrically distributed around the perimeter, creating a measuring plane with an initial position (level) related to the plane of the deck. The aim of the task was to record changes in the slope of the measured planes during the execution of various sea maneuvers. Measurements carried out in several cross-sections of the mast give a very clear picture of its work. This time task was limited to the abovementioned parameter, but in the future this type of data will allow to prepare a histogram of stress amplitudes which in neccery for fatigue analysis. In 2010 Fryderyk Chopin lost both masts during the cruise through Atlantic Ocean. One of the reasons for the failure could be material fatigue.

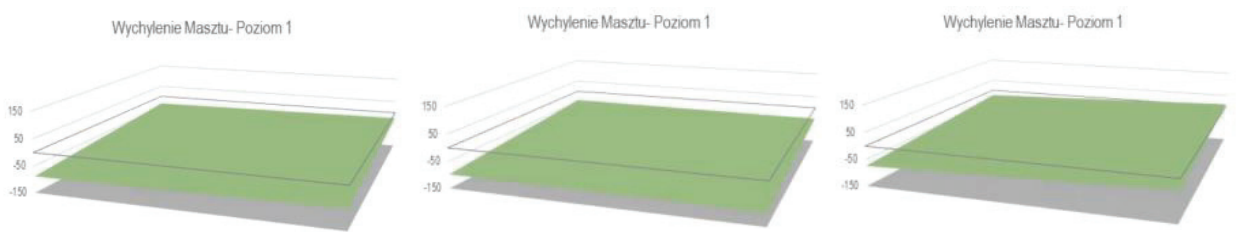

Fig. 4. Example frames from frame-based animation obtained from data processing for the lower crosssection in the second series of measurements [12]
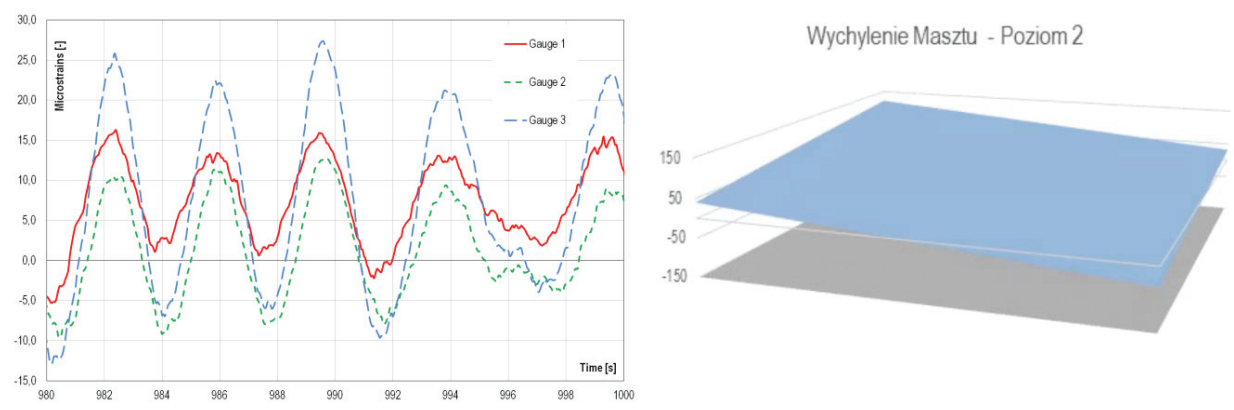

Fig. 5. Example of measured strains for 20 second period and the slope of measured plane in selected moment of measuring [12]

Two new domestic solutions of vibrating wire sensors, which are undertaking the task of meeting the requirements of building engineering are shown in [4][5][6]. Both solutions utilise self-exciting vibrations, the first one is based on the van der Pol generator, while the second one on the impulse exciter. Both solutions passed positively laboratory tests. Due to the application of typical and generally available in the market vibrating wire sensors in the impulse exciter, this solution became more practical one and holding promise for industrial implementations. 
The exciter subjected to step and impulse loads operated properly, was not loosing the synchronism and periods, as well as allowed to determine the instantaneous state of the wire elongation and the sensor base strain on the basis of the wire vibrations frequency.

The situation changes when the length of electric cables is increasing to a few hundred meters. At that time the exciter looses the rhythm being in agreement with the wire motion and looses the synchronism.

\section{FORMULATING THE MODEL OF THE VIBRATING WIRE SENSOR WITH ELECTRIC CABLES}

It was found, on the basis of preliminary measurements of the electric cables parameters that the most subjected to changes - on account of the length - are: longitudinal resistance and transverse capacity of cables. On account of that the two-port resistance-capacity network of $\mathrm{T}$ type was assumed as the model of electric cables. The scheme of the system in which sensor coils, cables, the source of the drive coil supply and equivalent parameters of the wire are exposed, is presented in Fig.6. The meaning of the equivalent mass and the remaining equivalent parameters of the vibrating wire are described in detail in paper [4].

Dynamic equations of the system motion were determined on the basis of the mentioned above scheme. As the generalised coordinates were assumed: current $i_{11}$ of coil $L_{1}$, current $i_{21}$ of coil $L_{2}$, voltage $u_{C 1}$ on condenser $C_{1}$, voltage $u_{C 2}$ on condenser $C_{2}$ and the position coordinate $x$ of the vibrating wire equivalent mass $m$.

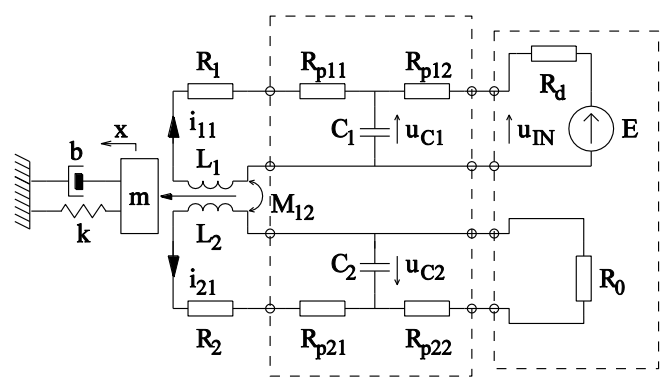

Fig. 6. Equivalent scheme of the vibrating wire sensor with electric cables

$$
L_{1}(x) \frac{d i_{11}}{d t}+i_{11} \frac{\partial L_{1}}{\partial x} \frac{d x}{d t}+M_{12} \frac{d i_{21}}{d t}-a \frac{d x}{d t}+\left(R_{p 11}+R_{1}\right) i_{11}+u_{C 1}=0
$$


(2)

$$
\begin{aligned}
& L_{2}(x) \frac{d i_{21}}{d t}+i_{21} \frac{\partial L_{2}}{\partial x} \frac{d x}{d t}+M_{12} \frac{d i_{11}}{d t}-a \frac{d x}{d t}+\left(R_{p 21}+R_{2}\right) i_{21}+u_{C 2}=0 \\
& u_{C 1}-\left(R_{1}+R_{p 12}\right)\left(i_{11}-C_{1} \frac{d u_{C 1}}{d t}\right)=E \\
& u_{C 2}-\left(R_{0}+R_{p 22}\right)\left(i_{21}-C_{2} \frac{d u_{C 2}}{d t}\right)=0 \\
& m \frac{d^{2} x}{d t^{2}}+b \frac{d x}{d t}+k x=\frac{1}{2} \frac{\partial L_{1}(x)}{\partial x} i_{11}^{2}+\frac{1}{2} \frac{\partial L_{2}(x)}{\partial x} i_{21}^{2}
\end{aligned}
$$

Parameters of the system were determined by direct measurements and also on the waveforms of naural wire vibrations and listed in Table 1.

Table 1. Parameters of the equivalent model for the electric cable $500 \mathrm{~m}$ long.

\begin{tabular}{|c|c|c|c|c|c|c|c|c|c|c|}
\hline Parameter & $L_{1}$ & $L_{2}$ & $M_{12}$ & $C_{1}$ & $C_{2}$ & $R_{1}$ & $R_{2}$ & $R_{p 11}$ & $R_{p 12}$ & $R_{p 21}$ \\
\hline Value & 4.63 & 4.63 & 0.37 & 104.9 & 58.8 & 93.4 & 93.1 & 27.1 & 27.1 & 27.1 \\
\hline Unit & $\mathrm{mH}$ & $\mathrm{mH}$ & $\mathrm{mH}$ & $\mathrm{nF}$ & $\mathrm{nF}$ & $\Omega$ & $\Omega$ & $\Omega$ & $\Omega$ & $\Omega$ \\
\hline Parameter & $R_{d}$ & $R_{0}$ & $E$ & $f$ & $\frac{\partial L_{1,2}}{\partial x}$ & $m$ & $b$ & $k$ & $a$ & $R_{p 22}$ \\
\hline Value & 303.5 & 9.85 & 2 & 800 & -0.166 & $1.85 \cdot 10^{-5}$ & $9.5 \cdot 10^{-5}$ & 558.3 & 0.0526 & 27.1 \\
\hline Unit & $\Omega$ & $k \Omega$ & $\mathrm{V}$ & $\mathrm{Hz}$ & $\mathrm{H} / \mathrm{m}$ & $\mathrm{kg}$ & $\mathrm{Ns} / \mathrm{m}$ & $\mathrm{N} / \mathrm{m}$ & $\mathrm{Vs} / \mathrm{m}$ & $\Omega$ \\
\hline
\end{tabular}

a)

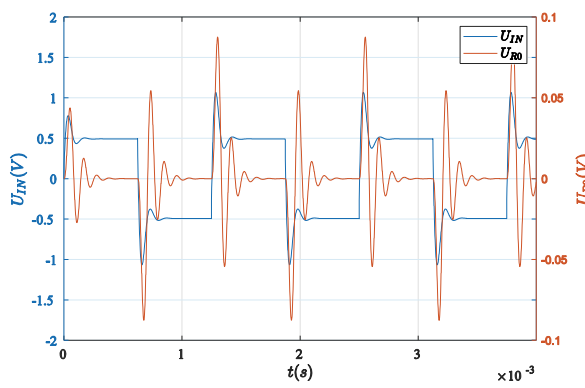

b)

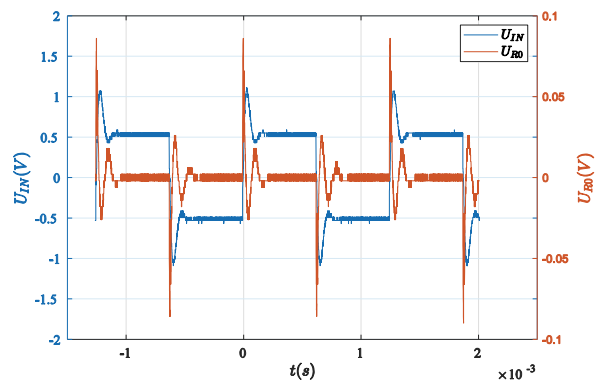

Fig. 7. Waveforms: a) obtained on the basis of the model, b) recorded by means of the oscilloscope

Figure 7 presents the voltage waveforms of the input $\mathrm{U}_{\mathrm{IN}}$ and output $\mathrm{U}_{\mathrm{R} 0}$ of the system obtained on the basis of derived equations and registered with an oscilloscope on the test stand. As can be seen, 
the results are in good agreement with each other and due to that, the formulated model became the base for further analyses.

\section{INFLUENCE THE LENGTH OF ELECTRIC CABLES ON THE WORK OF THE IMPULSE EXCITER}

The proper operation of the system under the field conditions depends on several factors. These are, first of all: length of electric cables, interactions between the drive coil and pickup coil circuits and electrical disturbances. In order to determine the influence of the cables length on the exciter operation equations (1) $\div(6)$ were applied. Substituting in them the autonomic source $E=E_{0} \operatorname{sign}(\omega t)$ by the controlled source $E=E_{0} \operatorname{sign}\left(U_{R 0}\right)$ the model of the ideal inertialess exciter was obtained.

The results of 5 simulations for 5 different length of cables: $500 \mathrm{~m}, 1 \mathrm{~km}, 2 \mathrm{~km}, 4 \mathrm{~km}$ and $6 \mathrm{~km}$ are presented in Fig.8.

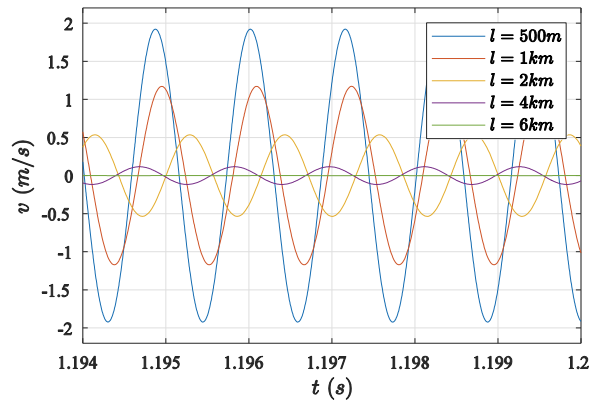

Fig. 8. Waveforms of the velocity of the wire middle point (reduced mass) for various lengths of cables.

As can be noticed, for the first four distances the system was self-exciting and obtaining vibrations of the frequency of $874.8 \mathrm{~Hz}$ corresponding precisely to the wire natural vibrations. In case of the first two distances the compatibility of the amplitude of the velocity of wire vibrations with the theoretical equation (6) derived in paper [5] was obtained. ( $i_{110}$ marks the steady-state of the current $i_{11}$ in the semi-period, after switching on the power supply).

$$
v=\frac{i_{110}^{2}}{\pi b} \frac{\partial L_{1}}{\partial x}
$$

The visible decrease of the amplitude of the wire vibrations was caused - first of all - by the decrease of the current value exciting the drive coil on account of the increase of the resistivity of electric 
cables. The phase shift of the current and wire waveforms had also meaning, the larger the longer cables.

\section{EXPERIMENTAL LABORATORY TESTS}

In order to verify the system properties resulting from theoretical analyses the experimental tests were performed. In these tests were applied: the impulse exciter described in paper [5], vibrating wire sensor of the Geokon Company and electric cables BITsensor PE-PVC, Fig.9. The system behaviour was tested for various length of electric cables, especially for: $1.5 \mathrm{~m}, 20 \mathrm{~m}, 40 \mathrm{~m}, 100 \mathrm{~m}, 160 \mathrm{~m}$ and $500 \mathrm{~m}$.

The oscilloscope screen during the wire vibrations recording at the application of cables $160 \mathrm{~m}$ long, are presented in Fig.10. Waveforms of the input voltage (from the pickup coil) and input voltage after filtration by means of the internal low-pass filter are seen there. All features of theoretical waveforms are shown in oscillographs, starting from the high value of the over-voltage impulse, low value of the voltage induced by the wire movement, up to several $\mathrm{kHz}$ voltage oscillations caused by power source switching. Investigations also confirmed the possibility of practical application of the exciter with electric cables of a length up to $500 \mathrm{~m}$ (tests were not performed for longer cables).

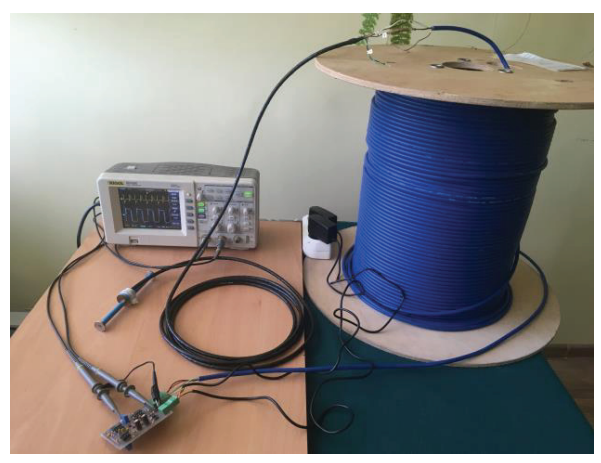

Fig. 9. The research set-up.

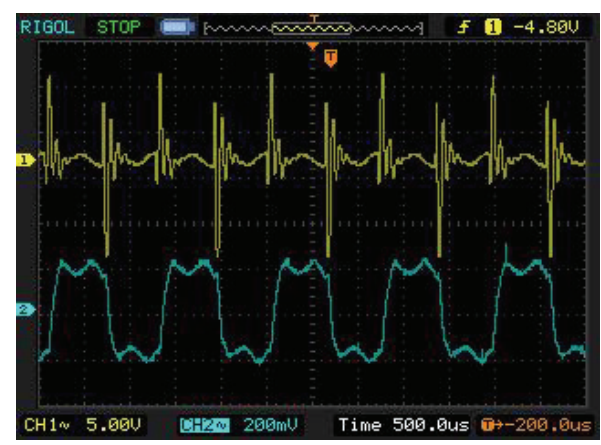

Fig. 10. Waveform of the input voltage $\left(\mathrm{U}_{\mathrm{R} 0}\right)$ before (yellow colour) and after filtration by the low-pass filter (turquoise colour), $\mathrm{l}=160 \mathrm{~m}$.

\section{CONCLUSIONS}

The analysis of cooperation of the vibrating wire sensor with the impulse exciter performed in the hereby paper indicate that the dynamic states of the circuit sensor-electric cables are the most 
important for the proper operations of the system. The maximal length of these cables, for which selfexcited vibrations will be kept, depends on parameters of electric cables. The theoretical analysis of the ideal case indicates that when typical components, available in the market, are used the operation of the system with electric cables $3 \div 4 \mathrm{~km}$ long, is possible.

Laboratory tests carried out for cables of various length confirmed the main conclusions obtained from theoretical analyses.

The next step is a field test with comparison of results to results obtained with adequate equpement already available on the market. Tests are planned on a bridge objects. As a final result the cheap modification of existing, already installed, SHM system is possible.

\section{REFERENCES}

1. W. Barcik, R. Sieńko, J. Biliszczuk, "System monitorowania konstrukcji mostu Rędzińskiego we Wrocławiu", Wrocław: Wrocławskie Dni Mostowe, 2011.

2. E Di Biagio, "A case study of vibrating-wire sensors that have vibrated continuously for 27 years". In Proc. of the 6th International Symposium on Field Measurements in Geomechanics, pages 445-458, 2003.

3. J. Biliszczuk, W. Barcik, J. Onysyk et al., "Rędziński Bridge in Wrocław - the largest concretecable-stayed bridge in Poland", Structural Engineering International 24 (2), May 2014, pp. 285-292.

4. G. Cieplok, "A wire transducer in a system with a van der pol oscillator and velocity feedback", Nonlinear Analysis: Modelling and Control, 22,(4):459 - 472, 2017.

5. G. Cieplok, "Self-exciting wire transducer for time-varying strain measurements", Journal of Dynamic Systems, Measurement, and Control, 140(11), 2018.

6. G. Cieplok, Ł. Kopij, "The application of self-oscillation in wire gauges", Journal of Theoretical and Applied Mechanics, 55(1):29-39, 2017.

7. L. Fedorowicz, M. Kadela, "Model calibration of line construction - subsoil assisted by experimental research", AGH Journal of Mining and Geoengineering, Vol. 36, no. 1:155-164, 2012.

8. L.E. Jacobsen, S.S. Cornelsen, "System and method for measuring the frequency of a vibrating object", March 18 2014. US Patent 8,671,758.

9. L.E. Jacobsen, D.L. Israelsen, J.A. Swenson, "Vibrating wire sensor using spectral analysis", August 24 2010. US Patent 7,779,690.

10. M. Kadela, Ł. Bednarski, "Wytyczne obserwacji ciągłej obiektów zlokalizowanych na terenach górniczych", Przegląd Górniczy, T. 70, nr 8:78-84, 2014.

11. W. Karwowski, Ł. Bednarski, M. Stoliński, "Monitoring mostów kolejowych", Warszawa/Jachranka, Seminarium IBDiM i PW Mosty Kolejowe, 2013.

12. W. Karwowski, M. Nazarczuk, K. Ulanowski et al, Engineering measurements on STS Fryderyk Chopin Internal Report, STS Fryderyk Chopin Foundation Seminary Politechnika na Fali, 2017.

13. W. Karwowski, A. Piotrowski, I. Morawska, K. Kosiński, B. Krawczyk, A. Kuk, "Engineering measurements on STS Fryderyk Chopin - Internal Report", Warsaw University of Technology Seminary Politechnika na Fali, 2016.

14. M. Kulpa, T. Siwowski, "Analityczna ocena trwałości zmęczeniowej pomostu ortotropowego mostu im. GrotaRoweckiego w Warszawie", Archiwum Instytutu Inżynierii Lądowej 18/2014, Politechnika Poznańska, s. 59-71.

15. B. Parkasiewicz, M. Kadela, P. Bętkowski, R. Sieńko, Ł. Bednarski, "Application of structure monitoring systems to the assessment of the behaviour of bridges in mining areas", IOP Conference Series: Materials Science and Engineering, 245(3):032018, 2017.

16. T. Siwowski, "Fatigue assessment of existing riveted truss bridges: case study", Bulletin of the Polish Academy of Sciences: Technical Sciences, 63(1):125-133, 2015. 


\section{LIST OF FIGURES AND TABLES:}

Fig. 1. Principle of operation of the strain transducer: 1 - wire, 2,7 - catches, 3 - electromagnet, 4 - switch, 5 - pulser, 6 - analyser, 8 - base.

Rys. 1. Zasada działania przetwornika strunowego. 1 - struna, 2,7 - zaciski mocujące, 3 - elektromagnes, 4 przełącznik, 5 - impulsator, 6 - analizator, 8 - obudowa.

Fig. 2. Sketch plan of the Structural Health Monitoring system on Rędziński Bridge and example of vibrating wire strain gauges in pylon foundation.

Rys. 2. Schemat systemu monitoringu technicznego na Moście Rędzińskim oraz przykład czujnika odkształceń umieszczonego w podstawie pylonu.

Fig. 3. STS Fryderyk Chopin side view with location of sensors in the first (circle) and the second (triangles) measurements series. Installation of vibrating wire strain gauges.

Rys. 3. Rysunek z widokiem z boku żaglowca Fryderyk Chopin z lokalizacją czujników pierwszej (koło) i drugiej (trójkąty) serii pomiarów. Instalacja czujników strunowych.

Fig. 4. Example frames from frame-based animation obtained from data processing for the lower crosssection in the second series of measurements.

Rys. 4. Przykład klatek z poklatkowej animacji otrzymanej w procesie obróbki danych otrzymanych dla niższego przekroju w drugiej serii pomiarów.

Fig. 5. Example of measured strains for 20 second period and the slope of measured plane in selected moment of measuring.

Rys. 5. Przykład pomierzonych przemieszczeń dla 20-sekundowego okresu czasu oraz pochylenie płaszczyzny w jednym z mierzonych momentów.

Fig. 6. Equivalent scheme of the vibrating wire sensor with electric cables.

Rys. 6. Schemat zastępczy czujnika strunowego z przewodami połączeniowymi.

Fig. 7. Waveforms: a) obtained on the basis of the model, b) recorded by means of the oscilloscope.

Rys. 7. Przebiegi: a) uzyskane na podstawie modelu, b) zarejestrowane oscyloskopem.

Fig. 8. Waveforms of the velocity of the wire middle point (reduced mass) for various lengths of cables.

Rys. 8. Przebiegi prędkości środka struny dla różnych długości przewodów połączeniowych.

Fig. 9. The research set-up.

Rys. 9. Stanowisko badawcze.

Fig. 10. Waveform of the input voltage $\left(\mathrm{U}_{\mathrm{R} 0}\right)$ before (yellow colour) and after filtration by the low-pass filter (turquoise colour), $\mathrm{l}=160 \mathrm{~m}$.

Rys. 10. Przebieg napięcia wejściowego $\left(\mathrm{U}_{\mathrm{R} 0}\right)$ przed i po filtacji wewnętrznym filtrem dolnoprzepustowym. $1=160 \mathrm{~m}$.

Table 1. Parameters of the equivalent model for the electric cable $500 \mathrm{~m}$ long.

Tabela 1. Parametry modelu zastępczego układu dla przewodu połączeniowego o długości $500 \mathrm{~m}$. 


\section{WPLYW DEUGOŚCI KABLI NA DYNAMICZNE POMIARY CZUJNIKAMI STRUNOWYMI}

Slowa kluczowe: czujniki strunowe, monitoring techniczny, maszt żaglowca, most, stany przejściowe, połączenia kablowe, drgania samowzbudne

\section{STRESZCZENIE:}

Artykuł porusza temat wpływu długości kabli na możliwość budowy systemów monitorowania konstrukcji z wykorzystaniem dynamicznych pomiarów strunowych. Rozważania przeprowadzono na przykładzie polskiego urządzenia pomiarowego przeznaczonego do dynamicznych pomiarów strunowych. Czujniki strunowe są szeroko stosowanym narzędziem w pomiarach i monitorowaniu konstrukcji. Znalazły zastosowanie w kontroli stanu technicznego mostów, tam, tuneli, stadionów. Swoją popularność zawdzięczają prostej budowie, pełnej odporności na warunki środowiskowe oraz bardzo długiej stabilności czasowej wynoszącej, wg badań Norweskiego Instytutu Geotechnicznego, ponad 30 lat. Ponieważ informacja o mierzonej wielkości jest przenoszona przez zmiany napięcia (częstotliwość) to czujniki strunowe mogą pracować z kablami o długościach dochodzących do $12 \mathrm{~km}$, co pozwala na umieszczanie czujników w dowolnych miejscach konstrukcji, często niedostępnych i podłączanie ich do urządzeń elektronicznych znajdujących się w łatwo dostępnym do serwisowania miejscu.

Jako przykład systemu monitorowania wykorzystującego statyczne pomiary strunowe, a wymagającego stosowanie czujników z bardzo długimi kablami, wskazano system monitorowania mostu Rędzińskiego przez rzekę Odrę we Wrocławiu. Możliwość stosowania czujników z dowolnie długimi kablami pozwoliła na wbudowywanie czujników bezpośrednio w konstrukcję mostu (część czujników znajduje się wewnątrz podstawy pylonu) i doprowadzanie sygnału pomiarowego w miejsce dostępne dla obsługi mostu, gdzie umieszczona została elektronika pomiarowa. Na obiekcie zainstalowano 96 czujników strunowych. Przykładem systemu monitorowania wykorzystującego dynamiczne pomiary strunowe jest system pomiaru odkształceń masztu żaglowca Fryderyk Chopin.

W celu określenia ograniczeń jakie wprowadzają kable łączące czujniki z rejestratorem danych wyznaczono dynamiczne równania ruchu opisujące elektronikę pomiarową wraz z czujnikiem i długimi przewodami połączeniowymi. Przyjęto 6 stopni swobody modelu. Przeprowadzono identyfikację parametrów modelu oraz wykonano symulacje cyfrowe. Otrzymane wyniki porównano z bezpośrednimi pomiarami urządzenia wykonanymi na stanowisku laboratoryjnym.

W celu sprawdzenia własności układu pomiarowego wynikających z analiz teoretycznych przeprowadzono badania eksperymentalne. W eksperymentach wykorzystano wzbudnik impulsowy, czujnik strunowy firmy Geokon oraz przewody połączeniowe BITsensor PE-PVC. W eksperymentach badano zachowanie się układu dla różnych długości przewodów połączeniowych, w szczególności dla: $1,5 \mathrm{~m}, 20 \mathrm{~m}, 40 \mathrm{~m}, 100 \mathrm{~m}, 160 \mathrm{~m}$ oraz $500 \mathrm{~m}$.

Przeprowadzona w pracy analiza współdziałania czujnika strunowego ze wzbudnikiem impulsowym wykazała, że podstawowym znaczeniem dla prawidłowego działania układu są stany dynamiczne obwodu czujnik-przewody połączeniowe. To w zależności od parametrów impedancyjnych cewek czujnika oraz parametrów elektrycznych przewodów połączeniowych zależy możliwość wzbudzenia się drgań o częstotliwości własnej struny. To od tych parametrów zależy maksymalna długość przewodów połączeniowych, dla której drgania samowzbudne struny będą się utrzymywać.

Analiza teoretyczna wykazała, że w przypadku zastosowania typowych komponentów dostępnych na rynku możliwa jest praca układu z przewodami dochodzącymi do ok. $3 \div 4 \mathrm{~km}$. Badanie jednak nie uwzględniały sprzężenia międzycewkowego, które może całkowicie wygasić drgania własne struny z jednej strony i być przyczyną wzbudzenia się niepożądanych drgań elektrycznych o częstotliwościach kilkukilohercowych z drugiej strony. Testy laboratoryjne przeprowadzone na przewodach o różnych długościach potwierdziły zasadnicze wnioski idące z analiz teoretycznych 